\title{
LOW-CARBON ECONOMY PLANNING IN THE PUBLIC SECTOR
}

\author{
Grzegorz Kunikowski, Eng PhD'
}

Faculty of Management, Warsaw University of Technology

\begin{abstract}
The article presents the results of analysis of low carbon economy planning in public administration, as well as technological and non-technological solutions present in Poland and the EU. The review of documentation, being a formal basis for dealing with problems by public administration and local authorities, and the analysis of sample programmes and plan indicate that the main determinant of low carbon economy development in Poland is the state of the natural environment, particularly air quality and availability of financial support for investments, which is dependent on the possession of specific planning documents. Technological solutions are economically verified as network parity, which indicates the importance of organizational, fiscal and financial solutions.
\end{abstract}

Keywords: general regional economics, alternative energy sources, government policy JEL codes: R10, Q42, Q48

\section{INTRODUCTION}

Low carbon economy, also called decarbonisation, assumes the use of low emission energy sources and the limitation of greenhouse gas emissions, $\mathrm{CO}_{2}$ in particular, the reasonable management of resources, also in circular economies, and energy efficiency. The initial background for a low-carbon economy are climate changes (United Nations Framework Convention on Climate Change - UNFCC) and the steady move away from use of traditional, fossil fuels to alternative fuels (OECD, 2010).

Low carbon economy also links to the concept of sustainable development, which is carried out by activities such as the improvement of air quality, the development of energy saving solutions and renewable energy technologies (RES), the promotion of material efficient manufacturing and industrial processes as well as ecological education, including professional and social education (Bednarski et al., 2017). The European Commission claims that 'climate change has long been recognised as one long-term shaping factor where coherent EU action is needed, both inside the EU and internationally' (European Commission, 2011a).

The problem included in the article is low-carbon economy planning in public administration on regional (voivodship) and local (community) levels. The issue is important also from a pragmatic perspective, as it is related to eligibility criteria for funding investment in 2014-2020 from the Operational Programme Infrastructure and Environment, and the influence of clean air on health and life quality. The issue of low emission has a negative impact in this context.

The term low carbon emission pertains to emissions from transport as well as those caused by local coal-based heating systems and individual home boilers. It is assumed that low emission is caused by

${ }^{1}$ Corresponding author: Narbutta 85, 02-524 Warsaw, Poland, Grzegorz.Kunikowski@pw.edu.pl, +4822 234843 
all chimneys up to $40 \mathrm{~m}$ of height, that is most building houses, communal and public buildings.

The financial perspective for 2014-2020 is the last Poland can use for supporting infrastructural investment. The role of emission criteria grows when selecting investment and technological solutions, and defining public investment policies. However, having the Low Emission Programme by a community is a required condition for funding investment in the Operational Programme Infrastructure and Environment 2014-2020 within priorities linked to climate protection ${ }^{2}$.

The article aims at reviewing and analysing issues linked to the low-carbon economy from the perspective of planning duties in public administration as well as technological and social challenges.

The scope of work includes the review of main EU strategies, national and regional (voivodeship) ones as well as an analysis of low-carbon technologies in the EU and Poland within sectors.

\section{LOW CARBON ECONOMY IN STRATEGIES AND REGULATIONS}

The main EU strategic documents are: 'A Roadmap for moving to a competitive low carbon economy in 2050', 'Energy Efficiency Plan 2011'. From the financial perspective 2014-2020, according to rules by the European Regional Development Fund, member states are obliged to spend part of financial means on low-carbon projects. The quota for more developed regions has to be higher than $20 \%$, for regions in transition - higher than $15 \%$, and more than $12 \%$ for less developed regions ${ }^{3}$.
For respective voivodeships, the following national strategies have to be mentioned: Energy Policy Poland 2030 (Ministerstwo Energii, 2009), National Spatial Development Concept (Resolution No 239 of the Council of Ministers) and Regional Operational Programmes (RPO) 2014-2020.

The main national regulations refer to the legal functioning of communities: Act on local government, Environmental protection law, Act on access to information about the environment and its protection, public participation in environmental protection and environmental impact assessments, Act on spatial planning and development spatial planning and Construction Law. Issues linked with fuel and energy are: Energy Law, Act on Energy Efficiency, Act on renewable energy sources and Act on electromobility and alternative fuels. Moreover, local regulations as detailed by regional operational programmes ${ }^{4}$, local low-emission programmes (PGEs) and programmes for limiting low-emissions (PONEs) are of significant importance.

\section{TECHNOLOGIES IN A LOW-CARBON ECONOMY}

International Energy Agency prognosis (IEA, 2010, $2017 \mathrm{a}$; b) indicates that among RES solutions currently available, only photovoltaic, on-shore wind and electric cars are technologically and commercially advanced enough to be used in energy transformation. By commercial maturity, we understand the ability to compete with conventional solutions as reaching grid parity, when commercialization is based on pure market rules, without subsidies and public subsidies.

Other low carbon technologies still need more research and development. Thus, non-technological

\footnotetext{
${ }^{2}$ Sample investment of low-emission are thermo-modernization of buildings, development of utilization of RES and development of public transportation.

${ }^{3}$ Polish territory has a diversified state of regional development and the share of investment for low carbon economy applications is $12.5 \%$ from EUR 9,198,911,747.

${ }^{4}$ In Voivodeship Operational Programmes, low carbon economy is linked with the following actions: (1) support for generation and distribution of RES energy (15 voivodeships); (2) promotion of energy efficiency and using RES in companies (12 voivodeships); (3) support for energy efficiency, intelligent energy management systems and using RES in public buildings and private buildings (16 voivodeships); (4) promotion of low emission strategies for all territories, urban areas, including support for sustainable urban mobility and adaptation (16 voivodeships); (5) increase of energy from cogeneration (4 voivodeships). The Lower Silesia region has additional funding possibilities (Wysoglad, 2017).
} 
solutions, resulting also indirectly in reducing emissions are more significant, e.g. outsourcing energy issues to specialized energy service companies, using energy performance contracts.

Sample organizational, fiscal and financial mechanisms, aimed at supporting the reduction of emissions and support decarbonisation are:

- Systems of fees to reduce traffic congestion and pollutants, fees for using transport infrastructure.

- Intelligent spatial planning and development of public transportation, limiting emissions from road transportation, rail and mainland water transportation.
- Emission limits of $\mathrm{CO}_{2}$.

- Taxation systems considering environmental issues.

- Introduction of legal requirements of energy standards for public buildings.

- Development of the international emission trade system (European Commission, 2011a; Bednarski et al., 2017).

Table 1 summarizes technological and non-technological solutions on a general EU level and detailed solutions customized for Poland (according to economic conditions, technical infrastructure and natural conditions), with sample applications.

Table 1. Innovative solutions in a low-carbon economy

\begin{tabular}{|c|c|c|}
\hline \multirow{2}{*}{ European Union } & \multicolumn{2}{|c|}{ Poland } \\
\hline & solution & sample application \\
\hline 1 & 2 & 3 \\
\hline \multicolumn{3}{|c|}{ Sector: energy } \\
\hline $\begin{array}{l}\text { renewable energy sources (wind, Sun, } \\
\text { biomass, heat pumps) } \\
\text { intelligent grid, carbon capture and } \\
\text { sequestration }\end{array}$ & $\begin{array}{l}\text { modernization of the National } \\
\text { Energy System (refurbishment of } 200 \\
\text { MW energy blocks modernization } \\
\text { of transmission and distribution } \\
\text { networks) } \\
\text { implementation of highly efficient } \\
\text { CHP } \\
\text { development of RES } \\
\text { continuous improvement of energy } \\
\text { efficiency }\end{array}$ & $\begin{array}{l}\text { programme led by the National } \\
\text { Center for Research and Development } \\
\text { dedicated, particularly, to energy } \\
\text { blocks of } 200 \text { MWe class } \\
\text { essential acts on RES and energy } \\
\text { efficiency } \\
\text { project of the Act on the promotion of } \\
\text { electricity generation in high-efficient } \\
\text { CHP }\end{array}$ \\
\hline \multicolumn{3}{|c|}{ Sector: transportation } \\
\hline $\begin{array}{l}\text { improvement of energy efficiency in } \\
\text { the automotive industry } \\
\text { alternative fuels } \\
\text { alternative fuels for advanced } \\
\text { powertrains (electric, hydrogen, fuel } \\
\text { cells) }\end{array}$ & $\begin{array}{l}\text { first generation biofuels } \\
\text { intermodal transportation } \\
\text { electromobility } \\
\text { urban Traffic management } \\
\text { development of infrastructure } \\
\text { supplying electric cars }\end{array}$ & $\begin{array}{l}\text { set of regulations dedicated to biofuels } \\
\text { and alternative fuels } \\
\text { promotion of the smart city concept } \\
\text { low-carbon economy plans } \\
\text { the Act on Electromobility and } \\
\text { Alternative Fuels }\end{array}$ \\
\hline
\end{tabular}


Proceedings of the 2018 International Scientific Conference 'Economic Sciences for Agribusiness and Rural Economy' No 1, Warsaw, 7-8 June 2018, pp. 103-108

Table 1 - cont.

\begin{tabular}{|c|c|c|}
\hline \multirow{2}{*}{ European Union } & \multicolumn{2}{|c|}{ Poland } \\
\hline & solution & sample application \\
\hline 1 & 2 & 3 \\
\hline \multicolumn{3}{|c|}{ Sector: industry } \\
\hline $\begin{array}{l}\text { application of advanced resource } \\
\text { and energy efficient processes and } \\
\text { machines in industry } \\
\text { recycling materials }\end{array}$ & $\begin{array}{l}\text { limiting emission in the cement sector } \\
\text { energy efficiency in chemical and steel } \\
\text { industries } \\
\text { development of auto-generations in } \\
\text { energy-intensive enterprises }\end{array}$ & $\begin{array}{l}\text { legal obligation for energy audits in } \\
\text { companies } \\
\text { criteria for using best available } \\
\text { technologies (BAT) }\end{array}$ \\
\hline \multicolumn{3}{|c|}{ Sector: buildings } \\
\hline $\begin{array}{l}\text { Increasing energy performance } \\
\text { standards for buildings } \\
\text { 'intelligent' buildings with near zero- } \\
\text { energy balance } \\
\text { using RES technologies integrated } \\
\text { with buildings } \\
\text { implementing energy saving equipment } \\
\text { and installations } \\
\text { local district heating }\end{array}$ & $\begin{array}{l}\text { systematically increasing energy } \\
\text { performance for buildings } \\
\text { new materials and construction } \\
\text { technologies } \\
\text { new zero-energy buildings } \\
\text { Implementing RES }\end{array}$ & $\begin{array}{l}\text { Promotion of Building Energy } \\
\text { Management systems, optimizing } \\
\text { energy utilization } \\
\text { Support for modernization } \\
\text { the New Energy Efficient Act and its } \\
\text { role for buildings }\end{array}$ \\
\hline \multicolumn{3}{|l|}{ Sector: agriculture } \\
\hline $\begin{array}{l}\text { improvement of fertilising } \\
\text { management } \\
\text { biogasification } \\
\text { improvement of feed } \\
\text { promotion of extensive agronomy and } \\
\text { agriculture } \\
\text { sustainable improvement of productivity } \\
\text { carbon sequestration in soil and forest } \\
\text { areas } \\
\text { production of liquid biofuels }\end{array}$ & $\begin{array}{l}\text { low carbon agronomy methods } \\
\text { waste management including the } \\
\text { development of biogas }\end{array}$ & $\begin{array}{l}\text { dedicated support for agricultural } \\
\text { biogas plants in the novelization of the } \\
\text { RES act, including the implementation } \\
\text { of a dedicated support scheme and } \\
\text { preferences in the auction system }\end{array}$ \\
\hline
\end{tabular}

Source: own elaboration based on: European Commission (2011b); Mazurkiewicz and Pająk (2014); Ministerstwo Gospodarki (2015); Bednarski et al. (2017), IEA (2017c); Ministerstwo Energii (2017). 


\section{CONCLUSIONS}

National planning documents and legal regulations of a low-emission economy are convergent and closely related to EU policy. The programmes incorporated by public administration authorities in Poland refer to general regulations in the field of environmental protection, spatial planning, sharing information and domain areas. The basic planning documents for municipalities are Low-Emission Economy Plans, which complement other documents in the field of environmental protection (Air Protection Plans, Low Emission Reduction Plans).

Photovoltaic technologies, onshore wind energy and electric vehicles are considered to be the most developmental in the field of renewable energy sources. Organizational, financial and fiscal solutions, which limit emissions, include energy efficiency and financing mechanisms for low-emission investments. The significance of the maturity of RES technologies in terms of grid parity, economic competitiveness with conventional sources, achieved without subsidies and other forms of support, are also growing.

Regional Operational Programmes of voivodeships provide investment support in the field of a low-emission economy in the financial perspective of 2014-2020 in the scope of: generation and distribution of energy from renewable sources, including high-efficiency cogeneration, energy efficiency in public buildings, the housing sector and enterprises. Local activities are recommended, which are decided on by local governments, especially in urban areas focused on mobility and adaptation activities.

\section{Acknowledgements}

The article is the result of research in the project financed by the National Center for Research and Development entitled 'Highly specialized platform supporting civil emergency planning and rescue in the Polish public administration and organizational units of the National Firefighting and Rescue System', agreement DOB-BIO7/11/02/2015 realised by the consortium: Warsaw University of Technology (Faculty of Management), Medcore sp. z o.o.

\section{REFERENCES}

1. Bednarski, M., Kunikowski, G., Pysz, J., Müller, T. i Wróblewski, Ł. (2017). Gospodarka niskoemisyjna na pograniczu polsko-czeskim - wybrane uwarunkowania [Low-emission economy on the Polish-Czech border - selected conditions]. Wyższa Szkoła Biznesu w Dąbrowie Górniczej, Dąbrowa Górnicza.

2. European Commission (2011a). Commission from the Commission to the European Parliament, the Council, the Economic and Social Committee and the Committee of the Regions - A Roadmap for moving to a competitive low carbon economy in 2050. COM(2011) 112 of 08.03.2011.

3. European Commission (2011b). Commission from the Commission to the European Parliament, the Council, the Economic and Social Committee and the Committee of the Regions - Energy efficiency plan 2011 $(\operatorname{COM}(2011) 109$ final of 08.03.2011.

4. International Energy Agency (2010). Energy Technology Perspectives 2010: Scenarios and Strategies to 2050. Energy Technology Perspectives. OECD Publishing. Paris.

5. International Energy Agency (2017a). Energy Technology Perspectives 2017: Catalysing Energy Technology Transformations. Energy Technology Perspectives. Paris.

6. International Energy Agency (2017b). Energy Technology Perspectives 2017. Paris.

7. International Energy Agency (2017c). Tracking Clean Energy Progress 2017. Paris.

8. Mazurkiewicz, J., Pająk, K. (2014). Gospodarka niskoemisyjna: uwarunkowania i wyzwania. Zielona Energia [Low-carbon economy: conditions and challenges. Green Energy]. Wydawnictwo Adam Marszałek, Torun.

9. Ministerstwo Energii (2017). Kierunki Rozwoju Innowacji Energetycznych [Directions of Energy Innovation Development]. Warszawa.

10. Ministerstwo Gospodarki (2009). Polityka energetyczne Polski do 2030 roku [Energy policy of Poland until 2030]. Warszawa.

11. Ministerstwo Gospodarki (2015). Narodowy Program Rozwoju Gospodarki Niskoemisyjnej [National Program for the Development of Low-emission Economy]. Warszawa.

12. OECD (2010). Transition To A Low-Carbon Economy: Public Goals And Corporate Practices. Organization For Economic Co-Operation \& Development, Paris.

13. Uchwała Nr 239 Rady Ministrów z dnia 13 grudnia 2011 r. w sprawie przyjęcia Koncepcji Przestrzennego 
Zagospodarowania Kraju 2030 [Resolution No 239 of the Council of Ministers of 13 December 2011 regarding the adoption of the National Spatial Development Concept 2030]. Official Journal of the Republic of Poland 2012, item 252.

14. Ustawa z dnia 20 lutego 2015 r. o odnawialnych źródłach energii [Act of 20 February 2015 on renewable energy sources]. Journal of Laws 2015, item 478.

15. Ustawa z dnia 10 kwietnia 1997 r. Prawo energetyczne [Act of 10 April 1997 Energy Law]. Journal of Laws 2017, item 220.

16. Ustawa z dnia 11 stycznia 2018 r. o elektromobilności i paliwach alternatywnych [Act of January 11, 2018 on electromobility and alternative fuels]. Journal of Laws 2018, item 317.

17. Ustawa $z$ dnia 20 maja 2016 r. o efektywności energetyczne [Act of 20 May 2016 on energy efficiency]. Journal of Laws 2016, item 831.

18. Ustawa $\mathrm{z}$ dnia 27 kwietnia $2001 \mathrm{r}$. Prawo ochrony środowiska [Act of 27 April 2001 Environmental protection law]. Journal of Laws 2017, item 519.

19. Ustawa $z$ dnia 27 marca 2003 r. o planowaniu i zagospodarowaniu przestrzennym [Act of 27 March 2003 on spatial planning and development]. Journal of Laws 2003 No 80, item 717.

20. Ustawa z dnia 3 października 2008 r. o udostępnianiu informacji o środowisku i jego ochronie, udziale społeczeństwa $\mathrm{w}$ ochronie środowiska oraz o ocenach oddziaływania na środowisko [Act of 3 October 2008 on access to information about the environment and its protection, public participation in environmental protection and environmental impact assessments]. Journal of Laws 2017, item 1405.

21. Ustawa z dnia 7 lipca 1994 r. Prawo budowlane [Act of 7 July 1994 Construction Law]. Journal of Laws 1994 No 89, item 414.

22. Ustawa z dnia 8 marca 1990 r. o samorządzie gminnym [Act of 8 March 1990 on local government]. Journal of Laws 2016 item 446.

23. Wysoglad, M. (2017). Zarządzanie funduszami unijnymi w perspektywie finansowej 2014-2020 na Dolnym Śląsku [Managing EU funds in the 2014-2020 financial perspective in Lower Silesia]. Acta Universitatis Nicolai Copernici. Nauki Humanistyczno-Społeczne. Zarządzanie, 44 (3), pp. 135-145. 